\title{
Bush goes to war as budget boosts R\&D
}

Colin Macilwain, Washington

President George W. Bush announced his proposals for a 'war budget' on 4 February, which would see a record $\$ 112$ billion spent on research and development during the 2003 fiscal year, up 8\% from this year.

The main components of the increase which reflect the president's priorities of fighting the war against terrorism, homeland defence and economic growth - are a boost of $\$ 5$ billion for weapons development at the Pentagon, and an increase of $\$ 3.7$ billion in funding for the National Institutes of Health (NIH), announced last week (see Nature 415, 459; 2002).

The Bush proposal will now be considered by Congress, which will set a final budget by October, when the 2003 fiscal year begins.

"The budget provides for an unprecedented level of support for research and development," says John Marburger, President Bush's science adviser. "It is the first time a president has requested more than $\$ 100$ billion for research and development."

The proposal would increase the US government's total spending on basic research by $\$ 2$ billion to $\$ 25.5$ billion - almost $60 \%$ of it at the NIH.

The scientific community was split along now-familiar lines in its initial reaction to this massive increase, with physical and environmental scientists feeling left out by the huge increases at the NIH.

Michael Lubell, head of public affairs at the American Physical Society, points out that when the NIH and the Department of Defense are discounted, spending on the rest of the research and development portfolio will fall. "At the National Science Foundation, for example, everything apart from mathematics and biology is actually cut," he says. "This isn't a budget to be thrilled about."

Sherwood Boehlert (Republican, New York), chairman of the Science Committee in the House of Representatives, said in a statement: "Research spending - excepting the NIH - would remain anaemic under this budget."

But Howard Garrison, a spokesman for the Federation of American Societies for Experimental Biology, says that the NIH increase is "what we've all been hoping for", and adds: "The big elements of this are all looking good."

The budget documents themselves put strong emphasis on plans, spearheaded by Mitch Daniels, the director of the White House Office of Management and Budget, to base budgets on a more thorough assessment of agency performance (see Nature 415, 466-467; 2002).

The first part of this assessment, published in the budget, was harsh: the National Science Foundation (NSF) was the only agency in the entire government to get the 'thumbs up' for its financial management under the OMB's grading scheme. But NSF officials had to celebrate this accolade with imitation champagne from California, after

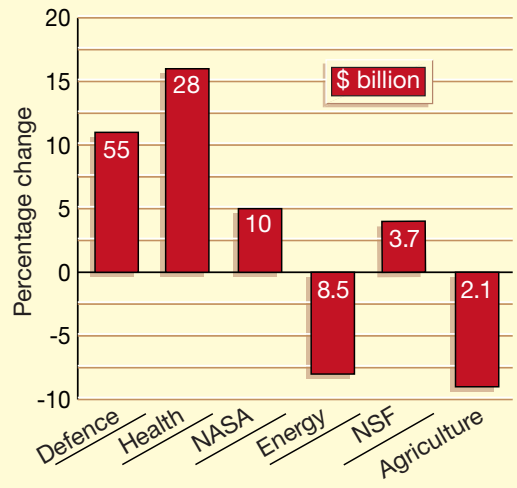

Battle stations: Bush's 2003 budget proposal takes the fight to health and defence.

their budget increase was held to a measly 3.4\% (see opposite).

Marcus Peacock, associate director of the $\mathrm{OMB}$, hints that the NSF will be rewarded for its management skills in future years. "This is the first year that we've attempted to link budget and performance," he says, predicting that additional responsibilities will be shifted to the agency soon.

Peacock also encourages scientists to drop their resistance to the OMB's plans to apply performance assessment to basic research. "I've been reading in a book that it took European mathematicians 300 years to accept the idea of negative numbers," he says. "I'm hoping we'll do better than that in getting people to accept performance assessment." www.whitehouse.gov/omb

\section{Funding freeze leaves high-energy physics facing cuts}

\section{Geoff Brumfiel, Washington}

The Department of Energy's Office of Science, which supports major research facilities across the country and is the United States' main sponsor of physics research, will receive no increase at all to its \$3.3-billion budget under President Bush's 2003 proposal.

Several programmes will be curtailed as a result of the funding freeze. In high-energy physics, for example, extra resources to upgrade the Tevatron at Fermilab, near Chicago, will come at the cost of closing down a fixed-target experiment at the Alternating Gradient Synchrotron at the Brookhaven National Laboratory in New York state.

The proposed halting of this experiment has alarmed Brookhaven officials. "We had been promised running of the experiment at least through 2003, and now we wake up to find that they've just taken it away," says Thomas Kirk, an associate director at the laboratory. "It's a very serious blow to our high-energy physics programme."

But John Marburger, the former Brookhaven director who now serves as Bush's science adviser, defends the emphasis on the Tevatron, which he says has a "window of opportunity" to search for the Higgs boson before Europe's Large Hadron Collider (LHC) begins operating in 2007. "Maybe they'll find it before the LHC switches on," he says.

Under the proposal, biological and environmental research at the energy department will decline sharply, from $\$ \mathbf{5 7 0}$ million this year to $\$ 504$ million next year, although department officials say that many of the cuts will affect projects that had been "earmarked" by Congress this year.

One bright spot in the Office of Science's proposal is $\mathbf{\$ 4 5}$ million in new funding for four nanotechnology research centres, the first of which will be built at Oak Ridge National Laboratory in Tennessee.

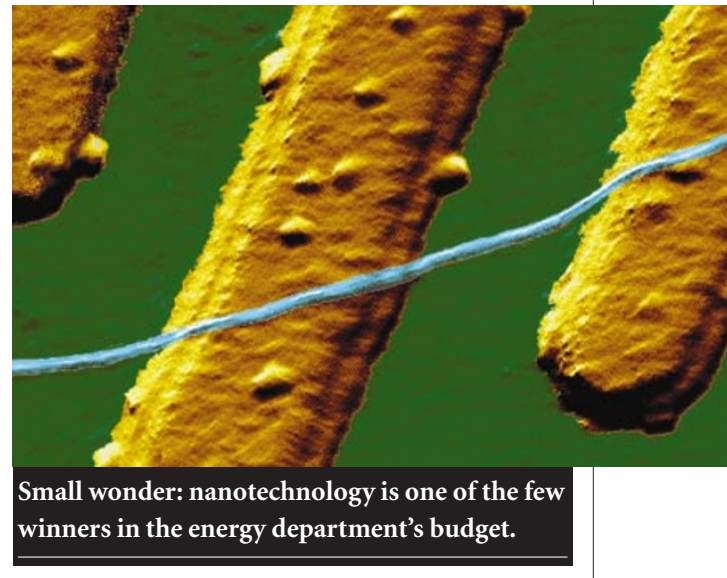

Although non-military science programmes at the Department of Energy will suffer, the National Nuclear Security Administration, which runs the department's nuclear-weapons research laboratories, will see its budget grow by $6 \%$ to more than $\$ 8$ billion. 


\section{NASA tunes in to nuclear power}

\section{Tony Reichhardt, Washington}

NASA plans to make major new investments in nuclear-powered rockets and spacecraft, its recently appointed head Sean O'Keefe said on 4 February as he unveiled the agency's budget proposal for the fiscal year 2003. But at $\$ 15.1$ billion, NASA's budget would be virtually unchanged from this year.

O'Keefe added that proposed missions to Jupiter's moon Europa and to Pluto will be scrapped to be replaced with a widerranging programme called New Frontiers, modelled after the agency's successful Discovery line of planetary spacecraft.

With a typical mission price tag of about $\$ 650$ million, New Frontiers will focus on studying the origins of life in the Solar System, as well as other priorities set by a forthcoming review of planetary exploration by the National Academy of Sciences. NASA will solicit mission concepts from laboratories inside and outside the agency this spring, and plans to choose the first winner next year.

The agency is set to make its first significant investments since the 1960s in space nuclear power ( $\$ 79$ million) and nuclear rocket propulsion ( $\$ 46.5$ million) during 2003. It sees these technologies as the best way to cut the time it takes to travel to the outer planets and to increase the working lives of probes and rovers sent to visit planets (see Nature 410, 626; 2001).

These and other technology investments account for much of the $12 \%$ increase in

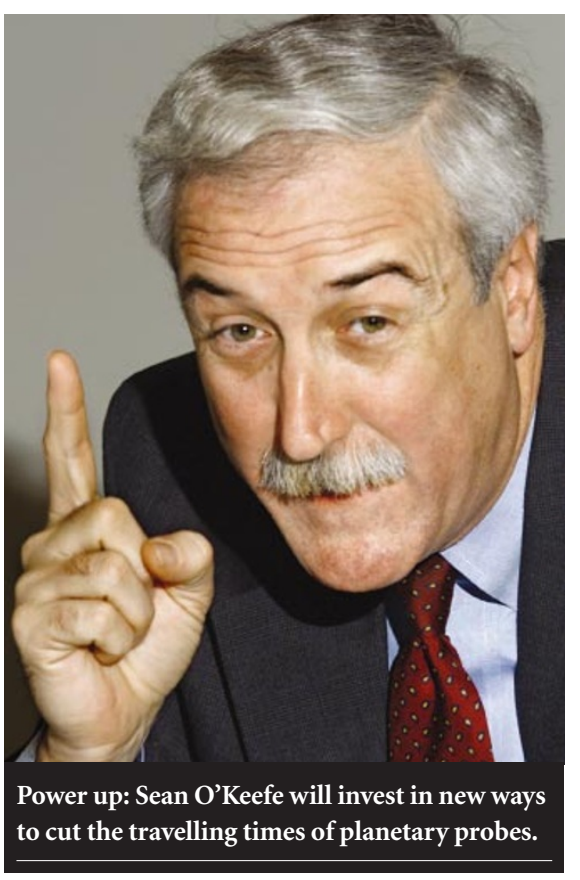

NASA's space-science budget, to \$3.4 billion. According the White House, the portion of NASA's total budget spent on research and development will grow by $5 \%$ to $\$ 10$ billion.

Funding for the troubled International Space Station drops by $13 \%$ to $\$ 1.5$ billion in the budget proposal. Agency managers have been given two years to solve its fiscal and managerial problems, or resign themselves to having a smaller, less capable station.

\section{Extra duties offset NSF gains}

\section{Virginia Gewin, Washington}

The National Science Foundation (NSF) has been put in charge of three new programmes in this week's budget proposal. But, despite being the only government agency praised for its financial management in a much-trumpeted recent White House assessment, it gets little financial reward.

The NSF — which funds most nonbiomedical university research in the United States - receives an increase of $5 \%$ in the budget proposed by its director, Rita Colwell. Government officials acknowledge that this is really worth just $3.4 \%$ when its new responsibilities are taken into account.

Under the proposal, the NSF will take charge of the Sea Grant programme, transferred from the National Oceanic and Atmospheric Administration; the environmental education programme at the Environmental Protection Agency; and a new water-quality programme to replace the toxic-substances hydrology programme at the US Geological Survey.

Apart from the new arrivals, the big winner at the NSF is the mathematics division (see Nature 414, 676; 2001), whose grant budget will grow by $\$ 30$ million to $\$ 180$ million. Other agency divisions, including astronomy, physics and chemistry, see their budgets fall by a few percentage points.

Two new major research projects that have been on hold for a year get the go-ahead in the budget. EarthScope, a network devoted to earthquake detection and research, will receive $\$ 35$ million and two prototype sites for the National Ecological Observatory Network will get \$12 million (see Nature 410, 854; 2001). Continued building of the Atacama Large Millimeter Array is allocated $\$ 30$ million.

And the impoverished graduate students supported by the foundation can look forward to an increase in their annual stipends, from $\$ 21,500$ to $\$ 25,000$.
Pentagon rise bypasses campuses

The budget will not do much for university researchers on the prowl for Pentagon funds despite its proposed \$5-billion hike in research and development at the defence department.

All of the increase is earmarked for weaponssystem development. The Department of Defense's $\$ 1.4$ billion in annual support for basic research will actually slip by $\$ 10$ million, while its appliedresearch funding slides by $7.5 \%$ to $\$ 3.8$ billion.

The main exception to this is the Defense Advanced Research Projects Agency, whose basic research programme will be boosted by almost a quarter to $\$ 176$ million, while its applied research budget grows by $15 \%$ to more than $\$ 1.2$ billion.

\section{Peer-review programme is rewarded}

The US Department of Agriculture said that it would double the funding next year for its National

Research Initiative (NRI), to \$240 million.

Unlike most research spending by the agriculture department, NRI grants are competitively peer-reviewed, making the programme popular with plant geneticists and other university researchers.

The rest of the agriculture department's research and development programmes would be cut back from $\$ 2.3$ billion this year to $\$ 2.1$ billion. But the department proposes small increases in funding for research into bovine spongiform encephalopathy and foot-and-mouth disease.

\section{Minority programmes win at WIH}

As expected, Anthony Fauci's National Institute of Allergy and Infectious Diseases (NIAID) is the biggest winner from Bush's proposal to increase the budget of the National Institutes of Health (NIH) by $16 \%$.

Under the proposal, the NIAID's budget would grow by $57 \%$ to $\$ 4$ billion, with most of the increase directed at bioterrorism research. The National Cancer Institute receives an increase of $12 \%$, and the National Center on Minority Health and Health Disparities will receive $18 \%$. Most other institutes would get an increase of 8-9\%.

Funds for HIV/AIDS research at the NIH grow by $10 \%$ to $\$ 2.8$ billion, including a $24 \%$ boost in vaccine research and $\$ 100$ million for an international fund to fight HIV/AIDS, malaria and tuberculosis.

\section{Technology scheme under siege}

One of the Clinton administration's favourite research programmes - the Advanced Technology Program (ATP) at the National Institute of Standards and Technology (NIST) - will be almost halved in size under the Bush proposal.

The proposal cuts the programme's budget from $\$ 185$ million to $\$ 108$ million. A similar plan to shrink the ATP — which the administration regards as an unnecessary subsidy for work that industry should do itself — was blocked by Congress last year.

This time, the administration also proposes extra construction funding for NIST, providing $\$ 67$ million for new laboratories at its main campuses in Gaithersburg, Maryland, and in Boulder, Colorado. 